infectious diseases means that the problem is likely to get bigger.

All this is compounded by the withdrawal of many major drug companies from research into antibiotics, and the long timescale for developing new ones (see page 260). Furthermore, persisting in an arms race against microbial resistance may prove futile: it is a race that bacteria are well equipped to win, having evolved mechanisms over millions of years that help them develop resistance to molecules secreted by competing microbes.

Many in the microbiology and immunology communities now believe there is a need for radical new strategies in fighting infectious disease. Developments in immunology and other fields are prompting a convergence towards a more holistic approach that takes into account the complex set of feedback loops between pathogens, host immune systems and our own microbiota.

Better understanding of the host-pathogen interactions at the molecular level may yield answers and open up new ways of thinking about pathogenesis. Rather than always seeking to kill bacteria, for example, molecules that slow their growth or spread may be enough to let the host microbiota and immune system outcompete them, particularly if ways can be found to stimulate or modulate either. Molecules that harnessed our own defences against pathogens would also have the benefit of being less selective for resistance.

Take, for example, Mycobacterium tuberculosis, the bacterium that causes tuberculosis. It infects one in ten people in North America and Western Europe, and one in three worldwide, but only a fraction of these will develop the full-blown disease, with the bacterium dormant or kept in check in the remainder. What tips the balance towards disease? As yet, we have little idea.

Our understanding of the ecology of our own microbiota is limited, as is the molecular basis of host immunity in response to infection. There is still much to understand - until recently, for example, scientists paid little heed to innate immunity, comprising immune cells and secreted molecules that react immediately but rather nonspecifically to pathogens. It has only recently been discovered to be much more complex and active than was previously thought.

Such ideas are outlined in an excellent US National Academies report, Treating Infectious Diseases in a Microbial World
"Better understanding of host-pathogen interactions at the molecular level may yield answers." (see http://fermat.nap.edu/catalog/11471.html). Infectious diseases have for too long been considered either from the point of view of the microbiologist, with a focus on the pathogen, or from the point of view of the immunologist, with a focus on the host. Basic microbiology, which has lately struggled to win support against competing fields, must not be neglected. But research agencies, universities and scientists should embrace approaches that unite microbiologists and immunologists in the study of infection biology.

\section{Patents for the people}

\section{Peer review comes to the patent office.}

$\square$ reat inventions are driven by good science and technology, but great patent applications succeed by exploiting arcane patent law. This is a paradox of the patent system, and is one reason why it is in danger of being overwhelmed by thousands of complex applications, each trying to stake out the biggest possible piece of the intellectual-property pie.

Both the US and European patent organizations are seriously overstretched: the US Patent and Trademark Office (USPTO) says it has more than a million applications in its backlog; and examiners at the European Patent Office in Munich went on strike last week to protest against their workloads.

Also last week, the USPTO held a meeting in Alexandria, Virginia, to examine a novel approach to the problem. The Community Patent Review project (http://dotank.nyls.edu/communitypatent) tries to place the patent process firmly back in the hands of scientists and engineers by asking them for feedback on pending applications.

Under the proposed system, researchers would volunteer to be informed whenever patent applications in their areas of expertise are published. They could then use an electronic bulletin-board to post any prior publications that might be relevant. They could also rank other postings in order of interest. Ideally, the result would be a well-ordered list of publications that the patent examiner could use to determine whether the application is truly innovative.

The idea was the brainchild of Beth Noveck of New York Law School and has won forthright backing from IBM. The computer says its support is part of a broader push for patent reform. Now the USPTO is pondering a pilot project of the idea. IBM would volunteer some of its own applications for initial review.

Unsurprisingly, perhaps, some of the patent lawyers who attended the USPTO meeting were unimpressed with the idea. They pointed out grounds for legal challenges to the result of the suggested process: if patent examiners ignored some of the comments they received, for example, they might be accused of "inequitable conduct", which in turn might invalidate the patent. Additionally, comments posted on the site could run foul of current law, which limits communication between patent examiners and outside sources while an application is under review.

Then there is the question of who would bother to participate in the process. For the most part, researchers take part in scientific peer review because the community expects it. No one expects anyone to review
"Patent peer review may be able to clean up some of the spurious claims of those looking to profit from vaguely worded applications." patents, and it is conceivable that the only people who come to the site would be rival companies, their lawyers, and cranky 'inventors' hocking cold-fusion reactors and perpetual-motion machines.

But similar pitfalls have not entirely undermined 'open' review systems in other spheres, and the USPTO should at least give the idea a try. Scientific peer review is often credited with keeping research honest, and patent peer review may be able to clean up some of the spurious claims of those looking to profit from vaguely worded applications. And even if it fails, the pilot could assist in the search for fresh approaches for dealing with the backlog. corporation, which obtains more patents than any other company, 